\title{
18-FDG PET/CT ile Belirlenen Kahverengi Yağ Dokusu Glukoz Uptake’i ile Açlık Kan Glukozunun İliş̧kisi
}

\author{
Şadiye ALTUN TUZCU ๑ $₫$ \\ Dicle Üniversitesi Tıp Fakültesi, Nükleer Tip Anabilim Dalı, Diyarbakır \\ Bu makaleye yapılacak atıf: Altun Tuzcu Ș. 18-FDG PET/CT ile Belirlenen Kahverengi Yağ Dokusu Glukoz Uptake’i ile Açlık Kan Glukozunun İlişkisi. \\ Türk Diyab Obez 2019;3: 145-148.
}

\begin{abstract}
ÖZET
Amaç: Enerji metabolizması ve kahverengi yağ dokusu arasındaki ilişki birçok çalışmada gösterildiğinden, supraklaviküler kahverengi yağ dokusunun glukoz uptake’ini, prediyabetli bireylerde 18F-FDG PET / CT görüntüleme yöntemi kullanılarak etkilenip etkilenmediğini araştırmayı amaçladık.

Gereç ve Yöntemler: Gazi Yaşargil Eğitim ve Eğitim Hastanesi Nükleer Tip Kliniğine Şubat-Mayıs ayları arasında başvuran kanser hastalarının retrospektif bir derlemesini yaptık. Yüz otuz bir hasta açlık kan glukoz düzeylerine göre iki gruba ayrıldı: normoglisemik grup (kan glukoz düzeyi $\leq 99 \mathrm{mg} / \mathrm{dl}, \mathrm{n}=71$ ) ve prediyabetik grup (kan glukoz düzeyi $\geq 100 \mathrm{mg} / \mathrm{dl}, \mathrm{n}=60$ ). Tüm hastaların vücut kütle indeksi hesaplandi. Ortalama SUVmax ve SUVmean kahverengi adipoz dokusu ve deri altı adipoz dokusu verileri, 18-FDG PET / CT ile ölçüldü. Bu çalışma Dicle Üniversitesi etik kurulu (119-2019) tarafından onaylandı. İstatistiksel analiz için iki ortalama arasındaki farkın önemlilik testi ve ki-kare testi kullanıldı.

Bulgular: Normoglisemik grup ile prediyabetik grup arasında ağılık, boy ve VKİ açısından fark yoktu. Her iki grupta cinsiyet dağılımında fark yoktu. Supraklaviküler bölgeden normoglisemik grubun kahverengi yağ dokusu SUVmax ve SUVmean değerleri prediyabetik gruba göre anlamlı derecede yüksekti (sırasılla $\mathrm{p}=0,022, \mathrm{p}=0,034$ ).

Sonuç: Çalışmamızda, prediyabetli bireylerde 18-FDG PET / BT ile belirlenen glukoz alımının düşük olduğu gösterilmiştir. Bu durum, kahverengi yağ dokusunun tüm vücuttaki glukoz ve enerji dengesi için önemli olabileceğini göstermektedir.
\end{abstract}

Anahtar Sözcïkler: Kahverengi yağ dokusu, Glukoz, Prediyabetik durum

\section{Relationship Between Fasting Blood Glucose and Brown Fat Tissue Glucose Uptake Determined by 18-FDG PET/CT}

\begin{abstract}
Aim: Since the relationship between energy metabolism and brown adipose tissue has been demonstrated in many studies, we aimed to investigate whether glucose uptake of supraclavicular brown adipose tissue is affected by using 18F-FDG PET / CT imaging method in prediabetic individuals.

Material and Methods: We conducted a retrospective review of cancer patients presented to Gazi Yaşargil Education and Training Hospital Nuclear Medicine Clinic within the period between February and May 2018. One hundred thirty one patients were classified according to their fasting blood glucose level into two groups: normoglycemic group (blood glucose level $\leq 99 \mathrm{mg} / \mathrm{dl}$, $\mathrm{n}=71$ ) and prediabetic group (blood glucose level $\geq 100 \mathrm{mg} / \mathrm{dl}, \mathrm{n}=60$ ). All patients body mass index was calculated. Data of average SUVmax and SUVmean brown adipose tissue and subcutaneous adipose tissue was measured with 18-FDG PET/CT. This study was approved by the ethics committee of Dicle University (119-2019). Independent-t test and ki-square test were used for statistical analysis.

Results: There was no difference between normoglycemic group and prediabetic group in terms of weight, height and BMI. There was no difference in gender distribution in both groups. Brown fat tissue SUVmax and SUVmean values of the normoglycemic group from the supraclavicular region were significantly higher than the prediabetic group $(\mathrm{p}=0.022, \mathrm{p}=0.034$, respectively).
\end{abstract}

ORCID: Şadiye Altun Tuzcu / 0000-0003-3326-5358 
Conclusion: In our study, it was shown that glucose uptake determined by 18-FDG PET / CT is low in prediabetic individuals. This situation show that brown adipose tissue can be important for the balance of glucose and energy in the whole body.

Key Words: Brown adipose tissue, Glucose, Prediabetic state

\section{GíRIŞ}

Kahverengi yağ dokusu (KYD) öncelikle küçük çocuklarda görülür ve artan yaşla geriler (1). Son zamanlarda erişkinlerde kahverengi yağ dokusunun(KYD) var olduğu gösterilmiştir (2-4). Ayrıca araştırmalar, KYD aktivasyonunun, enerji harcamasının düzenlenmesi ile ilişkili olduğunu göstermektedir. KYD’nin enerji metabolizmasındaki rolünün bir başka kanıtı da KYD aktivasyonunun, tüm vücut glukoz homeostazı ve artmış insülin duyarlılı̆̆ı ile ilişkili olabileceğinin gösterilmiş olmasıdır (5). KYD aktivitesinin, kronik enflamatuar bir durum olduğu düşünülen ateroskleroz üzerinde de faydalı bir etkisi olabileceğinin ileri sürülmüş olması da KYD’nin önemini bir kez daha arttırmıştır (6).

PET ve CT (PET/CT) kombinasyonu, KYD'nin tanımlanmasına izin verir, çünkü KYD, PET ve CT'de yüksek 18F-FDG alımı gösterir, ayrıca Hounsfield üniteleri (HU) kullanarak yağ dokusunun tanımlanmasına olanak sağlar $(7,8)$. Diyabet ve prediyabetik süreçlerin enerji metabolizmasındaki dengesizliklerden kaynaklandığı çok iyi bilinmektedir. Enerji metabolizması ile KYD arasında ilişkinin varlığının birçok çalışmada gösterilmesi nedeniyle, bu çalı̧̧mada prediyabetik bireylerde, 18F-FDG PET/ CT görüntüleme yöntemi kullanılarak supraklaviküler KYD'nin glukoz uptake'nin etkilenip etkilenmediğini araştırmayı amaçladık.

\section{GEREÇ ve YÖNTEMLER}

\section{Olgular ve Çalışma Kurgusu}

Gazi Yaşargil Eğitim ve Araştırma Hastanesi Nükleer Tip kliniğine Şubat 2018 ile Mayıs 2018 tarihleri arasında PET/ CT görüntüleme amacı ile başvurmuş hastalardan oluşturuldu. PET/CT görüntüleri mevcut olan hastalar retrospektif olarak seçildi ve çalışmaya dahil edildi. Yüz otuz bir hastadan açlık kan şekeri $\geq 100 \mathrm{mg} / \mathrm{dl}$ olan hastalar ve kan şekeri $\leq 99 \mathrm{mg} / \mathrm{dl}$ olan hastalar olmak üzere iki grup oluşturuldu. Kan glukoz düzeyini etkileyebilecek hastalığı olan hastalar, örneğin pankreas kanseri olan ve herhangi bir malignitesi olup karaciğere metastaz yapmış hastalar ve bilinen diyabetli hastalar da çalışmaya dahil edilmedi. Hastaların PET/CT çekimi başlamadan ölçülen kan glukoz düzeyleri, yaşı, boy ölçümleri ve vücut ağırlığı gibi özellikleri hasta dosyasından alındı. Hastaların boy ve vücut ağırlığı kullanılarak vücut kütle indeksi (VKİ) hesaplandı. Çalışma Dicle Üniversitesi Tip Fakültesi Etik Kurulu tarafından onaylandı(119-2019).

\section{Görüntüleme Prosedürü}

Sekiz saat açlıktan sonra, hastalara intravenöz olarak 18FFDG verildi (kan şekeri $<200 \mathrm{mg} / \mathrm{dL}$ ise) ve tüm vücut görüntüleri PET/CT tarayıcıdan alındı (Siemens 3D-TOF Siemens Medical Systems). Enjeksiyondan 55 ila 75 dakika sonra (9) düşük doz CT taraması $(80 \mathrm{~mA}, 120 \mathrm{kV})$ yapıldı. PET taraması, kafatasının tavanından uyluğun ortasına kadar 3D modda alındı. Tüm hastaların kahverengi yağ dokusu ve subkutan yağ dokusun SUVmax ve SUVmean değerleri hesaplandı. Kahverengi yağ dokusunun ölçümleri supraklaviküler bölgeden subkutan yağ dokusunun ölçümleri ise Lumbal 3 vertebra düzeyinden yapıldı (Şekil 1).

\section{İstatistiki Analiz}

Tüm sonuçlar ortalama \pm standart sapma olarak hesaplandı. Hastaların metabolik parametrelerinin karşılaştırılmasında independent-t test (iki ortalama arasındaki farkın önemlilik testi) kullanıldı. Verilerin normal dağılıma uygunluğu Kolmogorov-Smirnov testi ile değerlendirildi. Gruplar arasında cinsiyet farklılıklarını saptamak için ise ki-kare testi kullanıldı. İstatistiksel anlamlılık p $<0.05$ olarak tanımlandı. Tüm istatistiksel analizler SPSS $^{\text {mo }}$ yazılımı versiyon 18 kullanılarak yapıldı.

\section{BULGULAR}

Normoglisemik grup ile prediyabetik grup arasında ağırlık, boy, VKİ açısından fark gözlemedi. Her iki grupta cinsiyet dağılımı açısından fark saptanmadı. Normoglisemik grubun supraklaviküler bölgeden ölçülen kahverengi yağ dokusu SUVmax ve SUVmean değerleri prediyabetik gruptan istatistiki olarak anlamlı bir düzeyde yüksek saptandı (sirasiyla $\mathrm{p}=0,022, \mathrm{p}=0,034)$. Her iki grup arasinda subkutan adipoz doku SUVmax ve SUVmean değerleri açısından fark saptanmadi (Tablo 1).

\section{TARTISSMA}

$\mathrm{Bu}$ çalışmada prediyabetik hastaların KYD'sinin 18-FDG PET/CT ile saptanan glukoz uptakenin non-diyabetik kişilerden daha düşük olduğunu saptadık. Bu bulgu KYD’nin de glukoz metabolizmasında önemli bir rolü olabileceğini düşündürmektedir. Glukoz uptake’inin prediyabetik grupta düşük olması şimdiye kadar çok önemsenmeyen KYD’nin diyabet gelişimde önemli olabileceğini düşündürmektedir. Chondronikola ve ark. (5) yaptıkları bir çalışmada, insanlarda KYD’nin tüm vücut glukoz tüketimi üzerine 
Tablo 1: Normoglisemik grup ile prediyabetik grubun fiziksel özellikleri, kan şekeri düzeyleri, kahverengi ve subkutan yağ dokusu SUVmax ve SUVmean değerlerinin karşılaştırılması.

\begin{tabular}{lccc}
\hline & Normoglisemik grup $(\mathbf{n}=\mathbf{7 1})$ & Prediabetik grup $(\mathbf{n}=\mathbf{6 0})$ & $\mathbf{p}$ \\
\hline Cinsiyet $(\mathrm{kadın} / \mathrm{erkek})$ & $45 / 26$ & $37 / 23$ & $>0,05$ \\
\hline A ğılık $(\mathrm{kg})$ & $70,2 \pm 14,6$ & $71,3 \pm 13,2$ & $>0,05$ \\
\hline Boy $(\mathrm{m})$ & $1,64 \pm 0,08$ & $1,66 \pm 0,07$ & $>0,05$ \\
\hline VKİ $\left(\mathrm{kg} / \mathrm{m}^{2}\right)$ & $25,9 \pm 5,2$ & $25,7 \pm 4,5$ & $>0,05$ \\
\hline Glukoz $(\mathrm{mg} / \mathrm{dl})$ & $91,6 \pm 5,8$ & $109,2 \pm 7,6$ & $<0,001$ \\
\hline Supraklavikuler kahverengi yağ dokusu SUVmax & $0,82 \pm 0,44$ & $0,68 \pm 0,24$ & 0,022 \\
\hline Supraklavikuler kahverengi yağ dokusu SUVmean & $0,46 \pm 0,27$ & $0,38 \pm 0,13$ & 0,034 \\
\hline Subkutan adipoz doku SUVmax & $0,60 \pm 0,24$ & $0,64 \pm 0,21$ & $>0,05$ \\
\hline Subkutan adipoz doku SUVmean & $0,35 \pm 0,17$ & $0,40 \pm 0,16$ & $>0,05$ \\
\hline
\end{tabular}
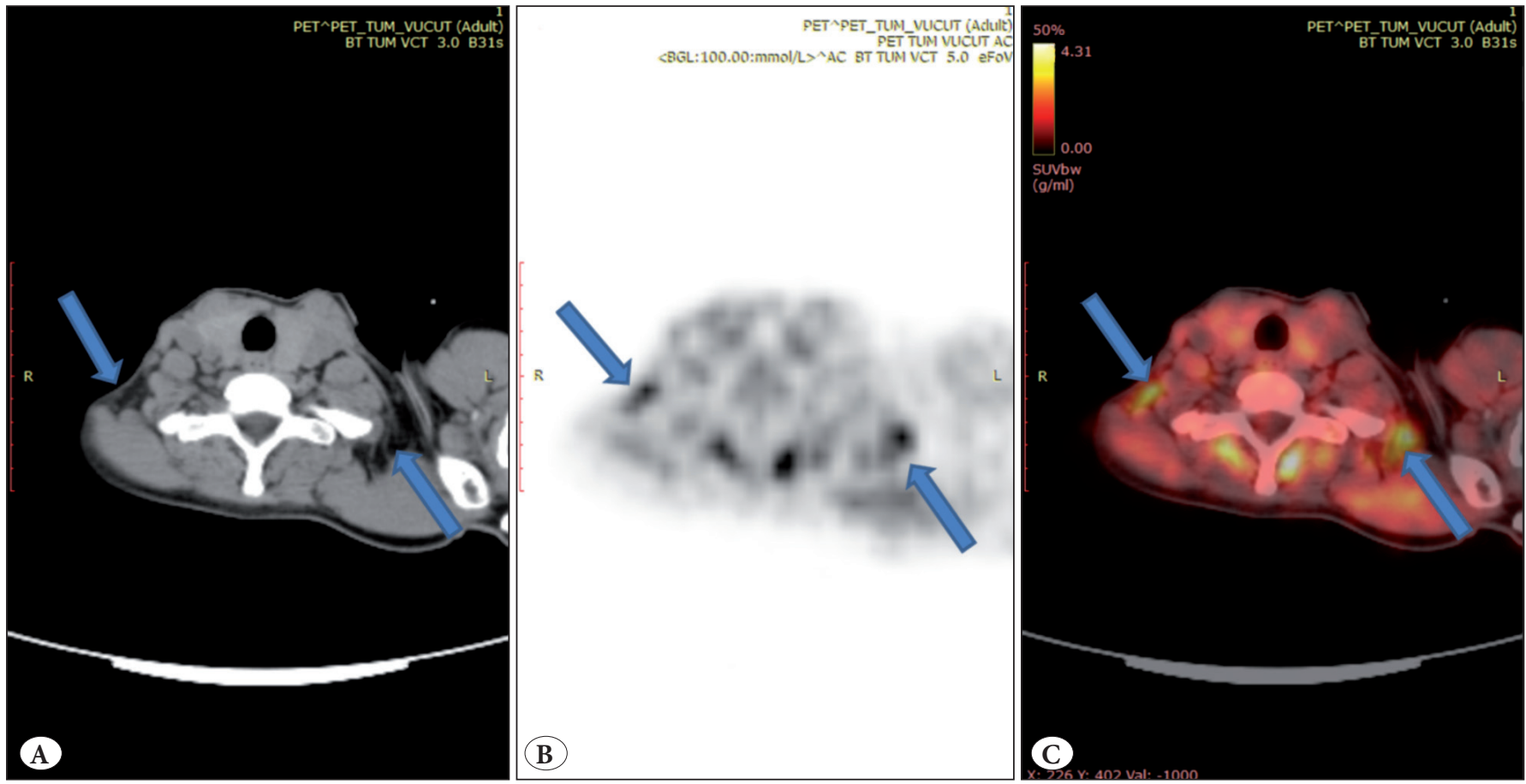

Şekil 1: Otuzyedi yaşında bayan hastanın Transaxial 18F-FDG PET/BT görüntüsü (A) BT imajı. (B) PET imajı. (C) Füzyon PET/ BT imaj. Supraklaviküler bölgede kahverengi yağ dokusu ile uyumlu alanlarda 18F- FDG akümülasyonu.

etkili olduğunu göstermiş ve aynı çalışmada KYD’nin glukoz homeastazı ve insulin sensitivitesi üzerine olumlu etkileri olduğunu vurgulamıştır (5). Bu çalışmada denekler soğuğa maruz bırakılmışlar böylelikle soğuk etkisi ile KYD daha da aktif hale getirilebilmiştir (5).

KYD’nin zayıflık ve öglisemi ile ilişkili olduğu bazı çalışmalarda öne sürülmüştür (4,5,10-12). Araştırıcılar KYD’nin bu özelliklerinin ortaya çıkması ile bu dokunun obezite ve diyabet gibi hastalıklardan korunmada önemli olabileceğini ortaya koymuştur.

KYD’nin obezite ve glukoz kontrolü üzerindeki etkilerini açıklayabilecek en önemli bulgusu KYD’nin diğer beyaz yağ dokusuna göre mitokondriden zengin olmasıdır. Mitokondri sayısının KYD'den fazla olmasının yanında bu mitokondrilerin içinde uncupling protein-1 (UCP-1) dediğimiz, protonların ATP sentazdan bağımsız olarak mitokondriyal matrikse tekrar girip kimyasal enerji yerine 1S1 üretmesini sağlayan bir proteinin varlığı önemli bir rol oynuyor gibi görünmektedir. Gerçekten de UCP-1 ekspresyonunun KYD’de daha fazla olduğu çalışmalarda gösterilmiştir (13). İnsan çalışmalarının yanında rodentlerle yapılan çalışmalarda KYD’nin glukoz ve serbest yağ asitlerini termogenezi sağlamak için kullandığı gösterilmiştir. Aynı hayvan modellerinde KYD'nin obezite, glukoz homeostazı ve insulin sensitivitesi üzerine etkili olduğu gösterilmiştir 
$(1,13,14)$. Bizim çalışmamızın sonuçları ile birlikte bahsedilen çalışmalar KYD’nin insulin sensitivitesinin oluşmasında ve diyabet patogenezinde rol oynayabilecek faktörlerden birisi olduğunu düşündürmektedir.

Çalışmamızın en önemli kısıtlayıcı durumu kanser hastalarında yapılmış olması ve retrospektif olarak düzenlenmiş olmasıdır. Özellikle bozulmuş kan glukozu olan hastalar çalışmaya dahil edilmişlerdir. Bilinen diyabeti olan hastalar ve insulin sensitivitesini etkileyecek ilaçları (metformin ve piogliatazon) kullanan hastalar çalışmaya dahil edilmemişlerdir. Hastaların PET/CT çekimi sırasında soğuğa maruz bırakılması KYD’nin daha da iyi tanımasını sağlayabileceği gibi KYD’nin metabolik durumunu da çok daha iyi yansitabilirdi. Ancak bu hasta grubunda bunun uygulanması mümkün değildir.

Çalıșmamızda prediyabetik bireylerde KYD’de 18-FDG PET/CT ile belirlenen glukoz uptake'nin düşük olduğu gösterilmiştir. Bu durum, KYD’nin tüm vücut glukoz ve enerji dengesi için önemli olabileceğini ortaya koymaktadır. Tüm vücutta var olan KYD miktarını ortaya koyan araştırmalar yapıp, onların kan glukoz düzeyine ve insulin direncine olan etkilerini araştıracak yeni çalışmalar yapmak bu konunun daha da iyi anlaşılmasına olanak sağlayacaktır.

\section{KAYNAKLAR}

1. Cannon B, Nedergaard J. Brown adipose tissue: Function and physiological significance. Physiol Rev. 2004;84:277-359.

2. Virtanen KA, Lidell ME, Orava J, Heglind M, Westergren R, Niemi T, et al. Functional brown adipose tissue in healthy adults. N Engl J Med. 2009;360:1518-1525.

3. van Marken Lichtenbelt WD, Vanhommerig JW, Smulders $\mathrm{NM}$, et al. Coldactivated brown adipose tissue in healthy men. N Engl J Med. 2009;360:1500-1508.

4. Cypess AM, Lehman S, Williams G, Tal I, Rodman D, Goldfine $\mathrm{AB}$, et al. Identification and importance of brown adipose tissue in adult humans. N Engl J Med. 2009;360:1509-1517.
5. Chondronikola M, Volpi E, Borsheim E, Porter C, Annamalai $\mathrm{P}$, Enerbäck S, et al. Brown adipose tissue improves wholebody glucose homeostasis and insulin sensitivity in humans. Diabetes. 2014;63:4089-4099.

6. Willerson JT, Ridker PM. Inflammation as a cardiovascular risk factor. Circulation. 2004;109:II2- II10.

7. Cohade C, Osman M, Pannu HK, Wahl RL. Uptake in supraclavicular area fat ("USA-Fat"): Description on 18F-FDG PET/CT. J Nucl Med. 2003;44:170-176.

8. Baba S, Jacene HA, Engles JM, Honda H, Wahl RL. CT Hounsfield units of brown adipose tissue increasen with activation: Preclinical and clinical studies. J Nucl Med. 2010;51:246-250.

9. Boellaard R, Delgado-Bolton R, Oyen WJ, Giammarile F, Tatsch K, Eschner W, et al. FDG PET/CT: EANM procedure guidelines for tumour imaging: Version 2.0. European Association of Nuclear Medicine (EANM). Eur J Nucl Med Mol Imaging. 2015;42(2):328-354.

10. Saito M, Okamatsu-Ogura Y, Matsushita M, Watanabe K, Yoneshiro T, Nio-Kobayashi J, et al. High incidence of metabolically active brown adipose tissue in healthy adult humans: Effects of cold exposure and adiposity. Diabetes. 2009;58:1526-1531.

11. Ouellet V, Routhier-Labadie A, Bellemare W, Lakhal-Chaieb L, Turcotte E, Carpentier AC, et al. Outdoor temperature, age, sex, body mass index, and diabetic status determine the prevalence, mass, and glucose-uptake activity of 18F-FDG-detected BAT in humans. J Clin Endocrinol Metab. 2011;96:192-199.

12. Matsushita M, Yoneshiro T, Aita S, Kameya T, Sugie H, Saito M. Impact of brown adipose tissue on body fatness and glucose metabolism in healthy humans. Int J Obes (Lond). 2014;38:812-817.

13. Bartelt A, Bruns OT, Reimer R, Hohenberg $\mathrm{H}$, Ittrich $\mathrm{H}$, Peldschus K, et al. Brown adipose tissue activity controls triglyceride clearance. Nat Med. 2011;17:200-205.

14. Stanford KI, Middelbeek RJ, Townsend KL, An D, Nygaard EB, Hitchcox KM, et al. Brown adipose tissue regulates glucose homeostasis and insulin sensitivity. J Clin Invest. 2013;123:215223. 